\title{
"Commoning" at the borderland: ecovillage development, socio-economic segregation and institutional mediation in southwestern Alentejo, Portugal
}

\author{
Ana Margarida Esteves ${ }^{1}$ \\ Instituto Universitário de Lisboa (ISCTE-IUL), Centro de Estudos Internacionais, Portugal
}

\begin{abstract}
This article sheds light on the exclusionary dynamics that emerge when the construction of commons-based alternative political ecologies does not take political economy considerations into account. It analyses the relationship between Tamera - Healing Biotope I, and the ecosystem, population and institutions of the region of southwestern Alentejo, Portugal, where this ecovillage is located. Tamera is based on a prefigurative process of "commoning", transplanted from Central European counter-culture, which created a "borderland" that spatially segregates and at the same time creates a point of contact between two contrasting cultural, ecological and socio-economic realities. However, maintaining the "borderland" granted the community access to the resources needed to develop its vision, while countering existing regulations, although eventually involving the state in the development of a new regulatory framework. Since the mid2000s, Tamera has been engaging in cultural dialogue with the local population, with the support of the municipality. The analysis raises the question of how to develop regulatory and financial instruments that support ecovillages in promoting inclusive strategies of economic sustainability, integrating them in placebased dynamics of regional development. The specificities of their biophysical and social processes must be taken into account, as well as their vocation as "testfields" for sustainability.
\end{abstract}

Keywords: Regional political ecology, ecovillages, regional development, social exclusion, cultural dialogue, regulatory innovation, Portugal

\section{Résumé}

Cet article traite de la dynamique d'exclusion qui peuvent émerger lors de la construction écologies politiques alternatives basées sur la gestion collective des biens communs ne tient pas compte des considérations d'économie politique. Il est basé sur l'étude de cas de la relation entre Tamera - Biotope guérison I, un écovillage situé dans la municipalité de Odemira (Portugal) et de l'écosystème, la population et les institutions de la région. La construction de Tamera est basée sur un processus de préfiguration « commoning " qui a été transplanté contre-culture en Europe centrale au sud-ouest de l'Alentejo. Ce processus a créé une " zone frontalière " qui sépare en même temps, crée un point de contact entre deux réalités culturelles, écologiques et socio-économiques contrastées. Cependant, cette "zone frontalière » a accordé l'accès communautaire aux ressources nécessaires pour développer leur point de vue, contrairement aux règlements en vigueur et impliquant l'Etat dans l'élaboration d'un nouveau cadre réglementaire. Depuis des années mi2000s, Tamera a fait la promotion d'un dialogue culturel avec la population locale, en comptant sur le soutien de la municipalité. L'analyse soulève la question de savoir comment élaborer des instruments réglementaires

\footnotetext{
${ }^{1}$ Dr. Ana Margarida Esteves, researcher, Centro de Estudos Internacionais, Instituto Universitário de Lisboa, ISCTEIUL, Lisbon, Portugal. Email: anamargarida.esteves "at" gmail.com. Acknowledgements: I gratefully acknowledge the financial assistance of the Portuguese Fundação para a Ciência e a Tecnologia (Bolsa SFRH/BPD/94495/2013) which enabled my affiliation to the Centro de Estudos Internacionais ISCTE-IUL (UID/CPO/03122/2013) and allowed me to conduct this research. My deepest gratitude to Spencer Campbell for his research assistance, and Filipe Moreira Alves, Gil Penha-Lopes and André Vizinho, from Faculdade de Ciências da Universidade de Lisboa, for graciously sharing the preliminary and final reports of the case study "Adaptation to Drought in Alentejo, Portugal", part of the EU-funded BASE - Bottom-Up Climate Adaptation Strategies for Europe. FP7/ Project BASE, Grant Agreement No. 308337. I also want to thank Michel Bauwens, Rogério Roque Amaro, Clara Carvalho, Spencer Campbell, Leila Dregger, Monika Alleveldt, Uri Ayalon, Filipe Moreira Alves, André Vizinho, Gil Penha-Lopes, Rafter Sass-Ferguson, Duarte Sobral, Manuel Nachtrub, Johannes Ewig, Juliette Baigler and two anonymous reviewers for their comments on previous drafts. Last but not least, I want to acknowledge the hospitality offered by Iris Golden and Herbert Kuehner in Vienna, Austria, as well as the encouragement to look deeper into the connection between $20^{\text {th }}$-century central European artistic movements and contemporary intentional community experiments.
} 
et financiers qui soutiennent les écovillages dans la promotion de stratégies inclusives de durabilité économique; et aussi les intégrant dans la dynamique de développement régional. Les spécificités de leurs processus biophysiques et sociaux doivent être prises en compte, ainsi que leur vocation de « testfields » pour la durabilité.

Mots-clés: écologie politique régionale, écovillages, développement régional, exclusion sociale, le dialogue culturel, l'innovation réglementaire, Portugal

\section{Resumen}

Este artículo aborda las dinámicas de exclusión que pueden emerger cuando la construcción de ecologías políticas alternativas basada en la gestión colectiva de bienes comunes no tiene en cuenta consideraciones de la economía política. Se basa en el estudio de caso de la relación entre Tamera - Healing Biotope I, una ecoaldea ubicada en el municipio de Odemira (Portugal) y el ecosistema, población e instituciones de la región. La construcción de Tamera se basa en un proceso prefigurativo de "commoning" que fue trasplantado de la contracultura de Europa Central hacia el suroeste de Alentejano. Este proceso creó una "zona de frontera" que segrega y al mismo tiempo, crea un punto de contacto entre dos realidades culturales, ecológicas y socioeconómicas contrastantes. Sin embargo, esa "zona fronteriza" concedió a la comunidad el acceso a los recursos necesarios para desarrollar su visión, contrariando los reglamentos existentes e involucrando el estado en el desarrollo de un nuevo marco regulatorio. Desde mediados de la década de 2000, Tamera ha promovido un diálogo cultural con la población local, contando para ello con el apoyo del municipio. Este análisis plantea la cuestión de cómo desarrollar instrumentos regulatorios y financieros que apoyen las ecoaldeas en la promoción de estrategias inclusivas de sostenibilidad económica y las integren en dinámicas de desarrollo regional. Estos instrumentos deben tener en cuenta las especificidades de los procesos biofísicos y sociales de estas iniciativas, así como su vocación como "laboratorios" para la sostenibilidad.

Palabras clave: Ecología política regional, ecoaldeas desarrollo regional, exclusión social, diálogo cultural, innovación regulatoria, Portugal

\section{Resumo}

Este artigo aborda as dinâmicas de exclusão que podem emergir quando a construção de ecologias políticas alternativas baseada na gestão coletiva de bens comuns não tem em conta considerações da economia política. Baseia-se no estudo de caso da relação entre Tamera - Healing Biotope I, uma ecoaldeia localizada no concelho de Odemira (Portugal) e o ecossistema, população e instituições da região. A construção de Tamera baseia-se num processo prefigurativo de "commoning" que foi transplantado da contracultura da Europa Central para o sudoeste Alentejano. Tal processo criou uma "zona de fronteira" que segrega e ao mesmo tempo, cria um ponto de contato entre duas realidades culturais, ecológicas e socioeconômicas contrastantes. No entanto, essa "zona de fronteira" concedeu à comunidade o acesso aos recursos necessários para desenvolver sua visão, contrariando os regulamentos existentes e envolvendo o estado no desenvolvimento de um novo quadro regulatório. Desde meados da década de 2000, Tamera tem vindo a promover um diálogo cultural com a população local, contando para isso com o apoio do município. Esta análise levanta a questão de como desenvolver instrumentos regulatórios e financeiros que apoiem as ecoaldeias na promoção de estratégias inclusivas de sustentabilidade econômica e as integrem em dinâmicas de desenvolvimento regional. Tais instrumentos devem ter em conta as especificidades dos processos biofísicos e sociais destas inciaitivas, assim como a sua vocação como "laboratórios" para a sustentabilidade.

Palavras-chave: Ecologia política regional, ecoaldeias desenvolvimento regional, exclusão social, diálogo cultural, inovação regulatória, Portugal

\section{Introduction}

This article is part of a project analyzing how commons-oriented, post-capitalist economic projects balance the realization of alternative livelihoods, while at the same time engaging with previously existing economic, cultural and institutional structures. It uses a regional political ecology approach to explore an understudied aspect of ecovillages, which is how the synergy between their ecological and social dimensions influences their relationship with the ecosystem, population and institutions of the region where they are 
located. The analysis is based on a study of the strategy adopted by Tamera - Healing Biotope $\mathrm{I}^{2}$, an ecovillage founded in 1995 in the municipality of Odemira, southwestern Alentejo, Portugal. It set out to develop a commons-based livelihood based on permaculture, renewable energy technologies and the decommodification of access to water, food and energy.

The article begins with a review on the role of ecovillages as "testfields" for sustainability. It includes a review of the commons and regional political ecology, shedding light on the marginalization of political economy in the construction of commons-based alternative ecologies. This absence contributes to the development of an exclusionary form of counter-power by ecovillages. The empirical analysis begins with a description of the "Healing Biotope model" as an "ideal type" of sustainable human settlement, rooted in mid-20 ${ }^{\text {th }}$ century Central European counter-culture, as well as the historical trajectory of Tamera as a prefigurative process of "commoning" that was transplanted into the community. This led to the emergence of a spatial "borderland", a point of segregation and contact between contrasting cultural, socio-economic and natural environments. A description of the socio-cultural, institutional and environmental dimensions of the project follows, and how it contrasts with the region around it. The final sections analyze the processes of cultural rapprochement and institutional dialogue in recent years that have been bridging the gap between Tamera and the region.

\section{Methodology}

Given the focus on context and process, I chose to use a hermeneutic methodology. The analysis is based on data collected during ethnographic fieldwork in Tamera between April and October 2015. Fieldwork included daily participant observation, as well as archival research and 15 semi-structured interviews with community members. The data collected during participant observation includes notes from informal conversations and interviews with neighbors and economic partners of Tamera, as well as public authorities and civil society leaders in the region. It was not possible to obtain detailed statistical data on revenue, funding sources or the demographic and socio-economic characteristics of visitors. This limitation results from the negotiation of conditions of access I was granted. There was the perception, on the part of the community, that surveys or accessing financial data would significantly interfere with the pace of activities in Tamera and compromise a level of privacy that the community wished to maintain. As a result, I decided to use an emic approach, in which the research participants' words and perspectives are the starting point of analysis. Data is based on estimations made by community members during interviews or conversations that took place during participant-observation. Quotes from interviews or conversations are transcribed in the original language of conversation, with the exception of one with the president of the Junta de Freguesia (village-level municipal administration) of Relíquias. This interview was conducted in Portuguese. The quotes were translated literally into English, so as to avoid correcting idiomatic expressions.

\section{Ecovillages as testfields for sustainability: the risk of exclusionary "commoning"}

The 1990s and early 2000s saw a worldwide multiplication of ecovillages. They became testing grounds for ecologically sustainable forms of human settlement, with the economic, institutional and cultural practices needed to support their functioning and to ensure their viability (Lockyer and Veteto 2013). This resulted from a growing awareness of the socio-economic and environmental externalities of the massindustrial mode of production, as well as the fossil fuel-led expansion of global supply chains and urban centers. Meanwhile some peripheral areas suffered desertion, impoverishment and environmental degradation. Power differentials and consumption gaps widened between core and periphery, and between elites and the rest of the population (LeVasseur 2013). Growing awareness of the interrelationship between contemporary ecological, socio-economic and cultural challenges, were rooted in a common factor - a crisis of the Cartesian/Newtonian mechanistic worldview, with the resulting disconnection from nature, decline in community, and hyper-individualism (Liftin 2013). This perspective contributed to the reformulation of intentional community-building on more holistic and ecologically oriented lines (Op. cit.).

\footnotetext{
${ }^{2}$ It will be referred simply as "Tamera" throughout the text.
} 
Ecovillages can be defined as prefigurative attempts to overcome the disconnection between culture and nature by "putting bioregional thought and permaculture methodology into practice at the community level" (Lockyer and Veteto 2013: 15). They are intentional human communities that use integrative design, local economic networking, cooperative and common property structures, and participatory decision-making, to minimize ecological footprints by internalizing production and consumption processes (Op. cit.). Their goal is to become "human-scale, full-featured settlements in which human activities are harmlessly integrated into the natural world in a way that is supportive of healthy human development and can be successfully continued into the indefinite future" (Gilman 1991: 10). Ecovillages may also be regarded as a concerted attempt to create, through "commoning", meaning the social process of creation and reproduction of the commons (de Angelis 2014), an "antidote to the extreme power differentials on various scales made possible by modern capitalist markets and politics" (LeVasseur 2013: 255). They are a "pan-global phenomenon (...) theoretically designed to suit local needs and thus reflect local culture" (Op. cit.). This means the reemergence of a concern for "place", and recognition of cultural specificities and grassroots selfdetermination that characterize many bottom-up responses to neoliberal globalization (Escobar and Alvarez 1992; Veltmeyer and Petras 2000).

In this sense, ecovillages can be seen as a materialization of the bioregional vision where "cultures of habitat" are privileged over arbitrary political boundaries (Nabhan 1997). This form of thinking from the standpoint of "place" implies a non-essentialist view of community and culture, which privileges rootedness in territories and ecosystems and "a sincere nod in the direction of the deep value of the natural world and the subjecthood of nonhuman beings" over identitarian concerns (Snyder 1995: 234). This allows for the accommodation, within the global ecovillage movement, of a variety of needs, standpoints and concerns that reflect their geographical positioning and culture (LeVasseur 2013). Despite this diversity within the movement, ecovillages tend to be, in their internal functioning, "susceptible to self-selective homogeneity, dogmatic purity, and assuming away cultural differences", often becoming "habitats for demagogues" and experiencing high rates of attrition and failure (Op. cit.: 255). This contradiction can be largely explained by the framing and strategies of implementation of the ecovillage concept, which favors post-materialistic goals and a neo-institutional approach to community building. These are reflected in the volume on community building edited by Joubert and Alfred (2014) for the Ecovillage Design Education program, which focuses on the development of internal structures and regulatory processes for group facilitation and collective decisionmaking, and less on the place of a new community in the political economy of rural areas.

The ecovillage concept is the brainchild of the Gaia Trust ${ }^{3}$, a charitable foundation based in Denmark, which, in response to the ecological concerns permeating the global commons, convened an international meeting of eco-communities in 1991 to discuss the further development and implementation of the concept. The meeting led to the creation of the Global Ecovillages Network (GEN) ${ }^{4}$, which is currently headquartered at the offices of its European hub in Findhorn, Scotland. ${ }^{5}$ GEN includes ecovillages located in the global North and South. These range from intentional communities built from scratch, with the goal of fulfilling the post-materialistic aspirations of predominantly middle and upper-class members (which predominate among ecovillages in the Global North), to traditional villages and urban neighborhoods that have implemented the ecovillage model, often with the support of the local state or NGOs, as a way of promoting energy efficiency, environmental sustainability and the economic well-being and self-determination of their members (Burke and Arjona 2013). However, variety has not prevented a predominant post-materialistic "Global North understanding of community and environmental problems" within GEN (LeVasseur 2013: 254-5).

The marginalization of political economy concerns mirrors the mainstream discourse on the commons, largely based on Elinor Ostrom's neo-institutionalist approach. Harribey (2011) claims that Ostrom's approach to the commons constitutes a renewal of neo-classical economics under the guise of neoinstitutionalism, which essentializes the commons by reducing it to "a particular form of property that cannot be separated from a permanent process of collective deliberation" (p. 102). This is because Ostrom's analysis

\footnotetext{
${ }^{3}$ http://gaia.org/ (last consulted on 30/05/2017)

${ }^{4}$ https://ecovillage.org/ (last consulted on 30/05/2017).

5 https://ecovillage.org/about/gen-structure/ (last consulted on 30/05/2017).
} 
focuses on the regulatory structures that support the collective management of the commons, while neglecting the nature of the goods and structural relations that constitute them within a market society ${ }^{6}$, within and beyond the process of "commoning" (p. 105). The commons may be constituted by a wide variety of goods, whose nature and form of regulation determines the conditions of access to the common pool, and therefore the extent to which the process of "commoning" promotes exclusionary dynamics that restrict or prevent some access. Ecovillages are not truly "common" - according to David Harvey:

"[n]ot all forms of the commons are open-access. Some, like the air we breathe, are open, while others, like the streets of our cities, are open in principle but regulated, policed, and even privately managed in the form of business-improvement districts. And some, like a common water resource controlled by fifty farmers, are from the very start exclusive to a particular social group." (2011: 103)

The right of access to the commons is often dependent upon private property rights. That is the case, for example, for the rotational irrigation systems of the huertas in the region of Valencia, Spain, in which access to water is dependent upon the size of the estate (Ostrom 1990), and indeed in most ecovillages where land was purchased.

Structural relations determine the extent to which, within a capitalist market society, individuals are able to access the commons, as well as actively participate and have their voices taken into account in decision-making (Harvey 2011). They include the extent to which productive and reproductive labor is gendered and socially divided, and included in "commoning" discussion at all. If labor is appropriated as the "primary mechanism by which a collective interest and mutual bonds are created" (Federici 2012: 49) then maximization of utility presupposed by homo economicus is operating. Instead, communing can promote identities that recognize the social, emotional and cultural dimensions of kinship, community and networks, as well as of institutions and human/nature relationships (Bollier and Helfrich 2012, 2015; Habermann 2012; Meretz 2012).

Another dimension ignored by Ostrom's approach is class stratification and its reproduction through "habitus" and the interchangeability of economic, cultural and social capital. Harvey (2011) argues that exclusionary tendencies in the material commons cut across the class and political spectrum:

The rich these days have the habit of sealing themselves off in gated communities within which an exclusionary commons gets defined. Radical groups can also procure spaces, sometimes through the exercise of private property rights (such as when activists buy a community-action center for some progressive purpose), from which they can reach out to further a politics of common interests. Or they can establish a commune or a soviet within some protected space. (p. 103)

The same happens with the Internet commons. Using an approach from Bourdieu, Schor et al. (2016) analyzed four open sharing economy platforms that aimed to construct relatively egalitarian economies. The authors found that, despite the goals and characteristics of the platforms, the presence of a large cohort of individuals who share a similar middle-class "habitus" promoted micro-level interactions that reproduced exclusionary mechanisms and inequalities existing in the larger economy. The participants in all four sites accessed the platforms through their social connections and deployed cultural capital via distinguishing practices that undermined relations of exchange and created difficulties completing trading, in a way which

\footnotetext{
${ }^{6}$ Harribey (2011) points out that the six institutional rules for successful commons identified by Ostrom (1990) (collective appropriation and provision rules that are clearly defined and aligned with local conditions, collective-choice arrangements, monitoring and conflict-resolution mechanisms, and gradual sanctions) are mainly backed with examples from pre-capitalist economies, in which the process of accumulation hadn't yet fully taken off. The case studies located in modern market economies had more complex processes of conflict regulation that involved the state (p. 104).
} 
created obstacles to the participation of users who did not share middle-class levels of education, cultural codes and proficiency in online platform usage.

The trajectory of the ecovillage movement indicates that, like the sharing economy platforms studied by Schor et al., it also ends ups reproducing in its midst the class fragmentation promoted by capitalism. This happens despite the stated goal of providing an antidote to the power differentials promoted by markets (LeVasseur 2013: 255). The multiplication of ecovillages in recent decades can be interpreted as the result of the emergence, among sectors of the upper and middle classes of the "Global North and South", of a set of post-materialist values which indicate a changing "habitus", resulting from what Inglehart (1997) calls a process of postmodernization. The author claims that, as modernization helped industrialized societies move from poverty to economic security, this led to a shift in life goals from survival and material security towards self-actualization and quality of life. Inglehart found these values to be most prevalent, and cross-nationally consistent, among the more highly educated, more articulate generations that grew up with affluence and choice in Western Europe and North America during the late $20^{\text {th }}$ century. The experience of being socialized into material affluence and high cultural capital, while confronted with mounting evidence of undesirable social and environmental side effects, contributes significantly to a shift in priorities from purely material goals towards self-actualization (Berman 1988; Tibbs 2011). It also tends to promote a mistrust of traditional sources of spiritual, political and cultural authority, as well as an alignment of consumer and lifestyle choices with progressive, ecological and anti-big business values (Ray and Anderson 2000).

Recent research on consumer behavior in the industrialized world indicates that these social sectors are also characterized by cosmopolitanism and concerns for the impact of consumer choices on environmental sustainability, intersectional equity and economic justice. They also tend to be at ease in the use of communication technologies and social networks (Carfagna et al. 2014). Implicit in this changing "habitus" is the search for a worldview and action model that is an alternative to the logics of instrumentality and domination that underlie modernity (Buell 2001; Tibbs 2011). The same can be said of the middle and upper class individuals that constitute the vast majority of the cohort of ecovillagers with post-materialist aspirations in the Global South. This is attested by Burke and Arjona's (2013) ethnographic description of Beatriz, a Latin American urban professional who "began her journey into ecovillages from a highly privileged economic position but with a profound and growing sense of discontentment" with the options made available to her by modernity (Op. cit.: 237). She was able to access information and develop arguments that countered peer pressure to conform to predominant life choices, and deconstructed her own internalization of mainstream values, which represented "intellectual barriers to imagining change" (p. 239). Her economic and social capital constituted a safety-net that granted her the material and psychological resilience needed to leave paid employment and embark in ecovillage living, as well as face its uncertain outcomes without fearing destitution and social exclusion. The authors contrast Beatriz's trajectory with that of the displaced and socially disadvantaged women of the Colombian Nashira Ecological Community, which grew out of the Association of Women Heads of Household (ASOMUCAF), an organization led by another elite individual: Angela Cuevas, a feminist, lawyer, and member of the women's peace network. ASOMUCAF was formed in 1993 to support women heads of household with low incomes and no access to capital. By 2003, the "contours of an alternative political ecology", based on community building and "commoning", emerged in discussions among participants, facilitated by Cuevas and her team of technicians, about how to fulfil strictly economic goals: housing, health, nutrition and better incomes (p. 243). The discussion materialized into an ecovillage project for 88 families to live and work together when Cuevas donated three hectares of her family's land and raised funds and technical expertise to develop the project.

These examples are more diverse than Ross Jackson's argument that "people in the South grasp the revolutionary potential of ecovillages much quicker than Northerners" because "they still have their social fabric more or less intact and see the ecovillage model as fully compatible with their village-based culture." (Jackson 2004: 8). While settlements such as Colufifa in Senegal existed before their identification as ecovillages, and base their activities on traditional knowledge (Kunze and Avelino 2015), many others want material progress - like the women of ASOMUCAF, many displaced by violence. Their social fabric, values and aspirations reflect this. Burke and Arjona argue that, as a result, "many of these urban dwellers actively reject 'village-based cultures' and ecovillage ideals of material simplicity, traditional/appropriate 
technologies, and food, water, and energy self-reliance in favor of hegemonic notions of wealth, development, and progress" (p. 246). Ecovillage development among such groups tends therefore to be the result of social interventions by the state or third sector organizations, which provide alternatives to hegemonic notions of what a "good life" is supposed to consist of, and facilitate access to the resources needed to materialize such visions. ${ }^{7}$

There are two other dimensions of the relationship between ecovillages and market society that remain understudied. One is the impact of the prefigurative strategy of building "cultures of habitat", based on overcoming the nature/culture dichotomy, and improving the relationship between ecovillages and the population, ecosystem and previously existing regional regulations. This is especially true around the common-property management of natural resources enclosed by commoners, including land and water. The other dimension is access to capital. Dawson (2012) points out that, from the mid-2000s onwards, there has been a concerted effort within the ecovillage movement to move from an inward focus on self-sufficiency to an outward focus on building alliances with neighbors, citizen groups and educational organizations. Lockyer and Veteto (2013) claim that this results from the difficulties experienced in setting up ecovillages, which requires resources and capital. This led those who "survived the test of time" to gear their strategy of economic sustainability towards "serving as educational models and living laboratories of sustainability" (p. 19). These difficulties result from the limited capacity that the Permaculture-based "techno-energetic systems" (Alvater 2005) of ecovillages have to produce surplus, in comparison to those based on fossil fuels and non-place-based mass production and consumption circuits. It is therefore necessary to raise external capital to meet their needs. The major source of external capital for ecovillages is the commercialization of their most abundant good, which is knowledge on social and environmental technologies and associated methodologies (Kunze and Avelino 2015). They also access public funds, such as those made available by sustainable development programs first created under the auspices of Agenda 21 in Europe, as well as networks of philanthropists (Op. cit.; LeVasseur 2013: 255).

Two related questions emerge from these understudied dimensions of ecovillages that ae pertinent to this study. What kind of relationships emerge between ecovillages, local populations and public authorities, as a result of:

a) the introduction of methods of land and water management that are not foreseen in existing regulations;

b) the processes of recruitment of donors, as well as clients for the ecovillages' knowledgebased products?

Analysis requires a multi-scalar regional approach (Blaikie 1985) that takes into account the relations between the inner dynamics of ecovillages, those of the ecosystem, institutions and culture of the region where they are located, and economic, natural and regulatory factors that extend beyond the region to the national and transnational spheres. Regional political ecology helps to understand processes through which agency (human and non-human) is rooted, the scale for negotiating coexistence, and the production of political-economic structures (Howitt 2006; Larsen 2016; Rocheleau 2011). It provides a framework which addresses issues of scale by taking into account not only how large-scale political processes affects regional ecologies, but also possible conflicts between localized "commoning" and trans-local ecological, socioeconomic and regulatory dynamics (Harvey 2011: 102). The study of ecovillages contributes to regional political ecology by providing insights on synergies between the natural and social dimensions of

\footnotetext{
${ }^{7}$ Katie Gilbert (2014) characterizes intentional communities as a white middle class phenomenon. She claims that "(...) intentional communities are rarely started, or even sought out, by those in extreme poverty, by immigrants or by a population with much racial diversity. Instead, well-educated, middle-class whites are disproportionately the demographic that forms and lives in these groups. Part of the reason may be that the systemic barriers built into the rest of society - like lack of access to education - constrain entry into this life too. (...) The poor, though they may share among themselves, typically don't look to communal living as a way to survive," (...) "It's kind of like, can [the poor] free themselves? How do you pull your own self up?"
} 
"commoning." These may provide the basis for a reimagined politics which enable small group dynamics to overcome the constraints of the existing system, and reclaim power.

However, what seems to be a good solution for natural resource management at the local scale may not aggregate up to the regional, national or global level (Harvey 2011). Given the tendency, attested by research, for self-selective homogeneity within ecovillages, their bottom-up counter-power may promote exclusionary dynamics that turn the commons into enclosures. Tamera is a privileged site for exploring these questions. The materialization of their vision in Portugal faced significant obstacles from national and European Union-level legislation. They also had to face a local culture with radically different social norms, as well as an ecosystem that differed significantly from that where their methodologies for water and land management were first developed. One may consider that Tamera created what Gloria Anzaldúa (1987) calls a "borderland", which segregates at the same time that it creates a point of contact and cross-fertilization between different cultural, socio-economic and natural realities.

\section{Fencing the "borderland": the "Healing Biotope" as a transplanted prefigurative process}

Tamera's project and trajectory does not emerge from local grassroots processes of collective action, based on a praxis-based reflection framed by local knowledge. Instead, it is a prefigurative process that results from materialization of a transplanted "ideal type" for a sustainable human settlement: the "Healing Biotope model." This process was marked by a regulatory void, as well as cultural estrangement from the local population.

The Healing Biotope model originates from criticism of Marxist thought by the co-founders of Tamera, German-born sociologist Dieter Duhm (b. 1942) and theologian Sabine Lichtenfels (b. 1954) , based on their own experience of mid and late- $20^{\text {th }}$ century Central European counter-culture. Their analysis is informed by conceptual structures derived mainly from German Idealism and psychoanalysis, as well as Eastern and Western theology and mystical thought. Since its foundation in 1995, Tamera has been gradually developing as a "testfield" for what is aimed to be a replicable model of a sustainable human settlement. The Healing Biotope is a conceptual framework or model based on insights gathered from the founders' political activism and intentional community-building in Central Europe from the 1960s to the early 1990s. Insights are drawn from what Duhm refers to as "sources of thinking and wisdom", which includes Nietzsche, Hegel, van Gogh, Rudolf Steiner, Jesus, Lao Tse, Wilhelm Reich, Prentice Mulford and Teilhard de Chardin. ${ }^{8}$ Direct experience was gathered in the Bauhütte project in the Black Forest in the late 1970s and early 1980s, of which Duhm was one the leading members. Its core purpose was to overcome the gap between theory and practice within Marxism as identified by Duhm and his comrades, the creation of intentional communities that aimed to prefigure the "emotional or mental depths of a 'concrete utopia"' by publicly dealing with the basic causes of intra- and inter-personal conflict that interfere with communal living. Another aim was to promote a communitarian economy based on a symbiotic, non-extractive and non-accumulative relationship with nature. ${ }^{9}$ Questions of sexuality, love, power and competition are central, as part of promoting an environment where solid and lasting partnerships can coexist with free sexuality, as well as forms of conflict resolution which can be applied in peace projects round the world. ${ }^{10}$ Prefiguring occurred through Selbstdarstellung (self-expression), in dialogical circles in which participants kinesthetically perform issues of their own inner development and social life, and receive feedback on their expression.

The Bauhütte project was terminated in 1987 as a result of, in the words of Duhm, "media slander and cult accusations." ${ }^{11}$ The fall of the Berlin Wall and the German reunification opened new oportunities. A group of former members of Bauhütte bought a former STASI ${ }^{12}$ compound in Bad Belzig, former GDR,

\footnotetext{
${ }^{8}$ https://www.tamera.org/what-is-tamera/the-founders/dieter-duhm/ (last retrieved on October 11, 2016).

9 https://dialogueireland.wordpress.com/1978/04/13/aao-an-anarchistic-organisation/ (last retrieved on October 10, 2016).

${ }^{10}$ http://www.shlur.com/2014/04/friedrichshof-otto-muehls-radical-commune/ (last retrieved on October 10, 2016).

${ }^{11} \mathrm{http}: / /$ dieter-duhm.com/node/4 (last retrieved on October 10, 2016).

${ }^{12}$ Ministerium für Staatssicherheit, official state security service of the German Democratic Republic (GDR).
} 
where they founded ZEGG - the Center for Experimental Cultural and Social design in $1991 .{ }^{13}$ A significant cohort of ZEGG founders moved with Duhm and Lichtenfels to Portugal in 1995, in order to start Tamera.

Dieter Duhm envisions a Healing Biotope as a prototype for sustainable human settlements, based on the creation of structures to promote trust and cooperation between humans and between the human species and nature. The key condition for a fully functioning Healing Biotope is full integration, coherence and harmony in the interaction within and between building community and ecosystem regeneration (Duhm 2015: 95). From this perspective, without functioning ecosystems, as well as self-sufficiency of water, food and energy at the local and regional level, a human community lacks material sustainability and either disbands or is absorbed by the mainstream. A functioning community is also fundamental for the cooperation between different skill areas that are necessary to support the regeneration of natural systems.

The Healing Biotope model can be characterized as the foundation of a "spiritual community." This term is used by spiritually oriented projects, such as Findhorn and Damanhur, which are often termed 'new religious movements' in academic literature but do not want to be identified as religions (Barker 2014: 237). Its social dimension involves the building of a social structure based on what are considered to be the core rules of the community: truth, mutual support and responsible participation in the whole. A key aspect of the process is the promotion of a spirituality based on the integration between the intellectual, affective and instinctual side of human beings, namely through what Duhm (2016) refers to as a conception of God beyond all religions, namely through the experiential realization of the immanence of Divinity in Nature and in everyday experience.

A core aspect of this process is what is understood in Tamera as "free love." Sabine Lichtenfels says this means the promotion of "a new erotic culture", aimed at "liberating love from fear", based on a "new connection of Eros and religion." ${ }^{14}$ This includes the promotion of full transparency in terms of erotic expression and its liberation from coercion and judgment, so that people may choose to openly assume sexual identities and behaviors that do not fit the patterns of monogamy or heteronormativity if they feel so inclined. The community offers support and solidarity with this process to promote and support full expression and individuation, while making sure this develops in a responsible and constructive manner. The promotion of "free love" is supported by techniques that include individuals working in dialogical circles in which intimacy and cooperation is created. The purpose is to regulate social interactions not according to fixed rules, but in a way that takes into account the changeable existential circumstances of the person and how they connect to wider community processes.

The ecological dimension of the Healing Biotope model consists in the building of a regenerative connection between human economic activity and local ecosystems, namely through the promotion of water, energy and food autonomy at the regional level. That happens through technologies and ecosystem management based on Permaculture, solar energy and biogas, as well as the development of a regional food autonomy network. Their purpose is to regenerate the ecosystem and contribute to the satisfaction of human needs in a way that promotes a symbiotic, non-accumulative relationship with nature (Duhm 2015).

One may therefore consider the materialization of a Healing Biotope in Tamera as a decades-old prefigurative process of "commoning", transplanted from Central Europe to Southwestern Iberia. The transplantation process included the conceptual framework, as well as a cohort of about thirty people that followed Duhm and Lichtenfels from ZEGG to Portugal. The most visible consequence of this process has been a spatial and cultural estrangement from the local population which, although more marked during the early years of the project, was still palpable at the time of fieldwork. When speaking to native inhabitants from the surrounding villages, I often realized that many of them were not aware of the existence of Tamera, even if they had lived in the region all their lives. Tamera seemed to be better known among neighbouring expatriates, or recent Portuguese "neo-rural" settlers who exchanged professional careers in large cities for a "back-to-the-land" lifestyle. For many years, Tamera opted to publicize its educational programs and other

\footnotetext{
${ }^{13}$ http://www.zegg.de/de/zegg-unterstuetzen/unterstuetzung-durch-deine-mitarbeit/35-gemeinschaft/zegggemeinschaft/128-geschichte-des-platzes.html (last retrieved on October 10, 2016).

${ }^{14}$ https://www.tamera.org/project-groups/feminine-peace-wisdom/global-love-school/ (last retrieved on September 26, 2016).
} 
activities across geographical barriers to like-minded people in Central Europe. It was only in the mid-2000s that the community received its first community members from other parts of the world, including Portugal. A civil servant from a neighboring village was a witness to the culture shock and mutual estrangement that marked the relationship between Tamera and the local population in the early years of the project:

Twenty years ago they [Tamera] were very closed. In the beginning, we were only allowed to enter their area in days chosen by them. They tried to block the roads that pass through their property. That caused many problems, because those roads are public roads. We even had to call the authorities, so that drivers could pass through. (...) Their appearance, the way they dressed, their way of being, the way they lived caused mistrust among the older people. (...). [Interview 14, October 2015]

Although, at the time of fieldwork, Tamera's relationship with the locals has improved significantly, its approach to issues of love and sexuality still caused significant estrangement. A long time neighbour of Tamera, herself a Central European expatriate, said during a casual conversation:

[t]hat whole question of love and sexuality is a barrier. The people of the region are very conservative. We have a [local] neighbour who lives right next to them but doesn't even want to hear anyone talk about Tamera for that reason. [Fieldnotes, October 2015]

During my visits to public spaces in Colos and Reliquias, I witnessed marked gender segregation in the way in which public spaces are occupied, as well as interactions which indicated the traditionally heteropatriarchal social norms among the locals. It is rare to see women in the central square of the villages or in sidewalk cafés. These areas are occupied mainly by men past retirement age, who sit around drinking, talking and playing cards. The local women, when not at home, tend to be found in inside cafés and restaurants. When sitting in public areas, they are generally accompanied by male relatives, or supervising children. The women who frequent such spaces without the company of children or male chaperones tend to be expatriates or Portuguese "neo-rurals", generally middle-class young people recently transplanted from metropolitan areas. On two occasions, I overheard conversations among older men in which the behaviour of those women was interpreted as a sign of sexual availability and "loose morals." Local informers of both genders, expatriate and native, also shared with me accounts of conversations they overheard or participated in which corroborated the interpretation that local older men make of such behaviour.

\section{Regulations}

Another consequence of the "transplantation" of the Healing Biotope model to Portugal was shock about the existing Portuguese regulatory framework. From its beginnings, Tamera developed without regulatory mechanisms capable of recognizing the linkage between their management of the natural commons and the development of a communitarian social structure. Their property regime was simply not recognized in existing legislation. According to a community member that acts as a liaison with the Global Ecovillage Network (GEN), this problem is not specific to Portugal, and is a structural problem in capitalist societies, which regard private or public property, the nuclear family and the individual as the basic units and foundations for legal personality:

[o]ne of the biggest challenges communities face is that there are no regulatory frameworks, at the national or international level, which recognize communities and their way of living, their specific form of land ownership and land management. Findhorn, for example, in terms of the law, is still registered and recognized as a trailer park! This despite being one of the most prominent and well-known communities in the world! Damanhur is still officially a bunch of villages... [Fieldwork notes, June 2015] 
The fact that Portugal is a member of the European Union adds further degrees of complexity to a prefigurative process of "commoning" natural resources, given the fact that it involves regional, national and supra-national levels of regulation and political decision-making. On the one hand, European integration created the conditions that allowed the founders of Tamera to purchase land and move to the region with the same residence and ownership rights as Portuguese citizens. On the other hand, it led to regulatory changes that further complicated project implementation. A community member, part of the initial cohort that founded Tamera and a community liaison person, claimed that:

[w] hen we first moved here, it was a bit different. There was no REN ${ }^{15}$ and RAN ${ }^{16}$, it was introduced later, the ecological reserve and the agricultural reserve, as a law, it was introduced later (...) we would just hand in the pedido, the request for building, and so the first houses were built this way (...) So we put in individual requests, for water treatment systems and for some of the lakes. Some were answered and some were never answered. I'll say it like this. And then the law has changed. In this process, some difficulties started, as to what is the limit of what we can build, and how it can be integrated in the legal framework. [Interview 6, June 2015]

The same respondent claims that these difficulties result from their arrival from a region of Europe with a very different organizational culture in the public sector. The justification presented was that Tamera spent its first 10 years "solidifying its vision", focusing on inner processes and having limited linkages to the local population. There was limited insight into local mores, with few insider contacts in the municipal administration which could have clarified and speeded authorization for construction. This made the early arrivals dependent upon advice from neighbors, often based on personal opinions and insights instead of verifiable facts:

We heard our neighbors, many of them said 'that's the way you do things here. You start building, it takes time, so you make the request for building permit and start building before the request comes, otherwise you will have to wait a very, very long time. But the request comes anyway, and then everything is ok.' Everything is legal and there is no problem. But then, with the European Union, things became much more difficult, more strict and more complex. [Interview 6, June 2015]

The absence of regulatory frameworks that take into account the specificities of ecovillages is also reflected in the kind of legal personality Tamera adopted. It regulates its relationship with the state and other stakeholders through an institutional setup which, although able to handle revenue, donations and taxation, is not seen by the community as being representative of Tamera's emerging commons-based livelihood. It includes three different legal entities. Ilos, Peace Research Centre, Lda. is the 'umbrella' company that owns the land and infrastructure of Tamera and deals with 'basic household expenses', such as food, healthcare and services. Revenue and donations are shared equally between the shareholders of Ilos, two non-profit associations known as G.R.A.C.E. and Associação para um Mundo Humanitário (AMH). The active

\footnotetext{
15 The acronym REN stands for Reserva Ecológica Nacional (National Ecological Reserve), a status attributed to areas, such as the coastal area of southwestern Alentejo, whose morphological characteristics and biodiversity are deemed fundamental for the ecological and socio-economic equilibrium of the region. Decreto-Lei n. ${ }^{\circ} 321 / 83$, approved on July 5 1983, regulates land use in RENs. It was updated by Decreto-Lei n. ${ }^{\circ}$ 93/90, of March 19, 1990 and Decreto-Lei n. ${ }^{\circ}$ 213/92, of October 12, 1992 (http://www.ccdr-a.gov.pt/index.php/ord/ren Last consulted on October 2, 2016). The fact that these regulations precede the creation of Tamera is symptomatic of the lack of insider knowledge of national legislation.

${ }^{16}$ RAN, "Reserva Agrícola Nacional" is a legal decree, approved in 2009, which regulates construction and land use in areas of Alentejo which, for their natural beauty, biodiversity and representativeness as examples of the application of traditional agricultural techniques are considered "Reserva Agrícola Nacional" (National Agricultural Reserve). (Art ${ }^{\circ} .2^{\circ}$ do Decreto-Lei $n^{\circ}$. 73/2009) (http://www.drapal.min-agricultura.pt/drapal/index.php/ran , last consulted on October 2, 2016)
} 
members of these associations are the community members of Tamera. AMH is responsible for environmental and technological research projects: the Solar Village Test Field, where renewable energy technology applications are researched and tested, landscape and ecosystem restoration, and the food autonomy network. The G.R.A.C.E. Association is responsible for educational projects such as a Global Campus program, as well as a planned International School, Escola da Esperança. The Association also manages a scholarship fund that allows people from "impoverished countries" or those who cannot pay course fees, to attend Tamera's educational and training initiatives. The information available to the public doesn't indicate, however, the amount of funding that is available, the target number of students the program aims to fund, or the criteria for selection. ${ }^{17}$

During a public discussion in September 2015, a source from the financial team indicated that Tamera's total expenses were an average of $€ 1$ million (US\$1.18m) per year. Tamera meets these costs with very limited linkages to the local economy. It wants to achieve economic sustainability, based on the commercialization of knowledge for an international clientele and an international donor circle. There is a needs-oriented financial approach that combines for-profit and non-profit elements and revolves around two major sources.

Tamera's major source of income is its educational and training programs, which cover over $60 \%$ of total community expenses. The second significant source of income is donations raised among an international Support Circle, which can be directed to meet 'basic household' expenses (infrastructure maintenance, food and energy supply, personal care services), as well as the investment budget, which covers individual projects like the Solar Village Test Field, food production and landscaping, as well as outreach activities like the Global Campus. The major source of recruitment for the Support Circle is Tamera's education and training courses, but also personal contacts, either from the community members' own professional or social networks, or established during special fundraising trips, most of which take place in central Europe or the USA. These trips are organized by the Grace Foundation, headquartered in Zurich, Switzerland and with branch offices in Portugal and Sonoma, California. The foundation's website says that it "(...) gives people with money, influence and other resources the opportunity to support a global system change by investing in a new planetary culture." ${ }^{18}$ According to the same source, a core motivation of this strategy was to pay all bank loans contracted in the early years of the project and achieve independence from the banking system, a goal that was successfully achieved by 2015.

\section{Crossing the "borderland": Tamera and Southwestern Alentejo}

They do not live in Portugal. They live in a world apart. They want to develop the project of two people from scratch. (...) They touch on a lot of questions that are taboo over here. [Fieldwork notes, October 2015]

These are the words of an expatriate who has been living in the vicinity of Tamera (Figure 1) for more than a decade. Tamera was indeed developed from scratch, with very limited linkages to the region and the resources of southwestern Alentejo, contrasting with its strong links to intellectual and activist circles in Central Europe. Its characteristics and trajectory raise the question of how such developments affect not only the capacity of an ecovillage to influence wider society, but how it can be inclusive in terms of the people who take part in a project, either as clients of its educational programs or as donors and community members.

\footnotetext{
${ }^{17}$ https://www.tamera.org/what-is-tamera/economy/ (last retrieved on November 30, 2016.)
}

${ }_{18}$ http://www.the-grace-foundation.org (Last retrieved on October 4, 2016). 


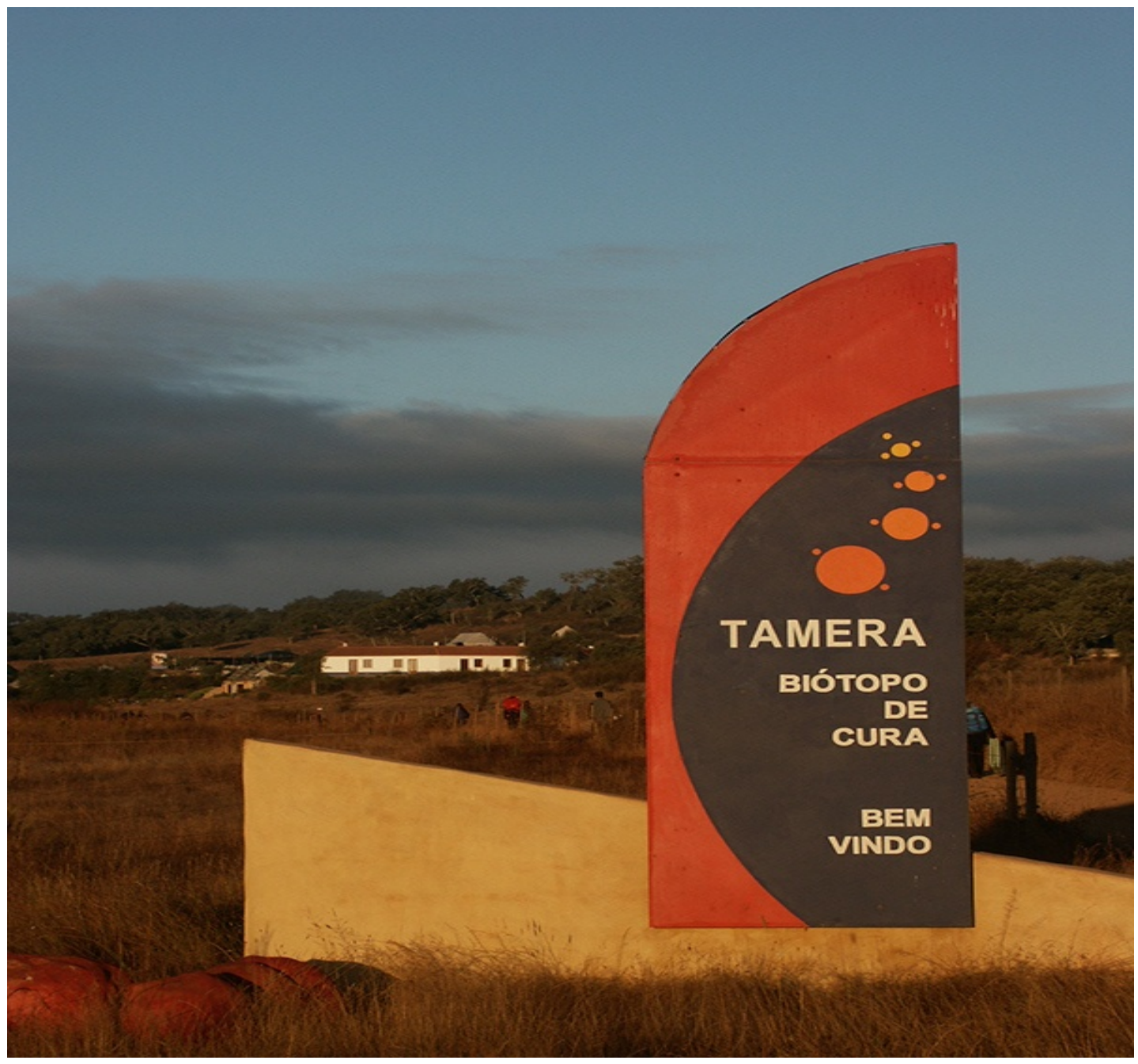

Figure 1: Tamera's main entrance. Source: $\underline{w w w . t a m e r a . o r g}$

Entering Tamera feels like crossing a materialized border between Iberia and Central Europe, with all their socio-economic, cultural and natural contrasts. The ecovillage is located in a region that is suffering a severe ecological, socioeconomic and demographic decline. The Alentejo is Portugal's biggest and most sparsely populated region, comprising only $7.2 \%$ of the total national population with a density of only 23.7 inhab. $/ \mathrm{km}^{2}$ in 2010 (Alves et al. 2015: 5). During the 20th century, the municipality of Odemira was subject to a process of natural and human desertification that turned it into one of the poorest in the European Union, as well as one of the most exposed to the effects of climate change. ${ }^{19}$ During the warm months of the year, the nearby villages of Colos (Figure 2) and Relíquias look almost deserted, except for their main squares and the odd sidewalk café, occupied by groups of elderly people, mostly men, who spend the afternoons chatting and playing cards. Sometimes they share the space with small, transient groups of Central or Northern

\footnotetext{
${ }^{19}$ Further information about this process can be obtained in the background study of the EU-funded Programa Operacional Regional do Alentejo 2014-2020, which can be downloaded from http://www.alentejo.portugal2020.pt/index.php/po-regional-do-alentejo-2014-2020 (last retrieved on March 7, 2016).
} 
European tourists and expatriates, who tend to keep to themselves and rarely mingle with the locals. These villages are located more than five kilometers away from Tamera. Their population decreased sharply between 1950 and 2011, from 3,515 to 931 inhabitants in Relíquias, and 3,045 to 1,005 in Colos. Tamera, in contrast with the homogenous, impoverished and ageing population of the surrounding villages, feels like a densely populated, youthful cosmopolitan hub, with a strong feminine presence in public spaces.

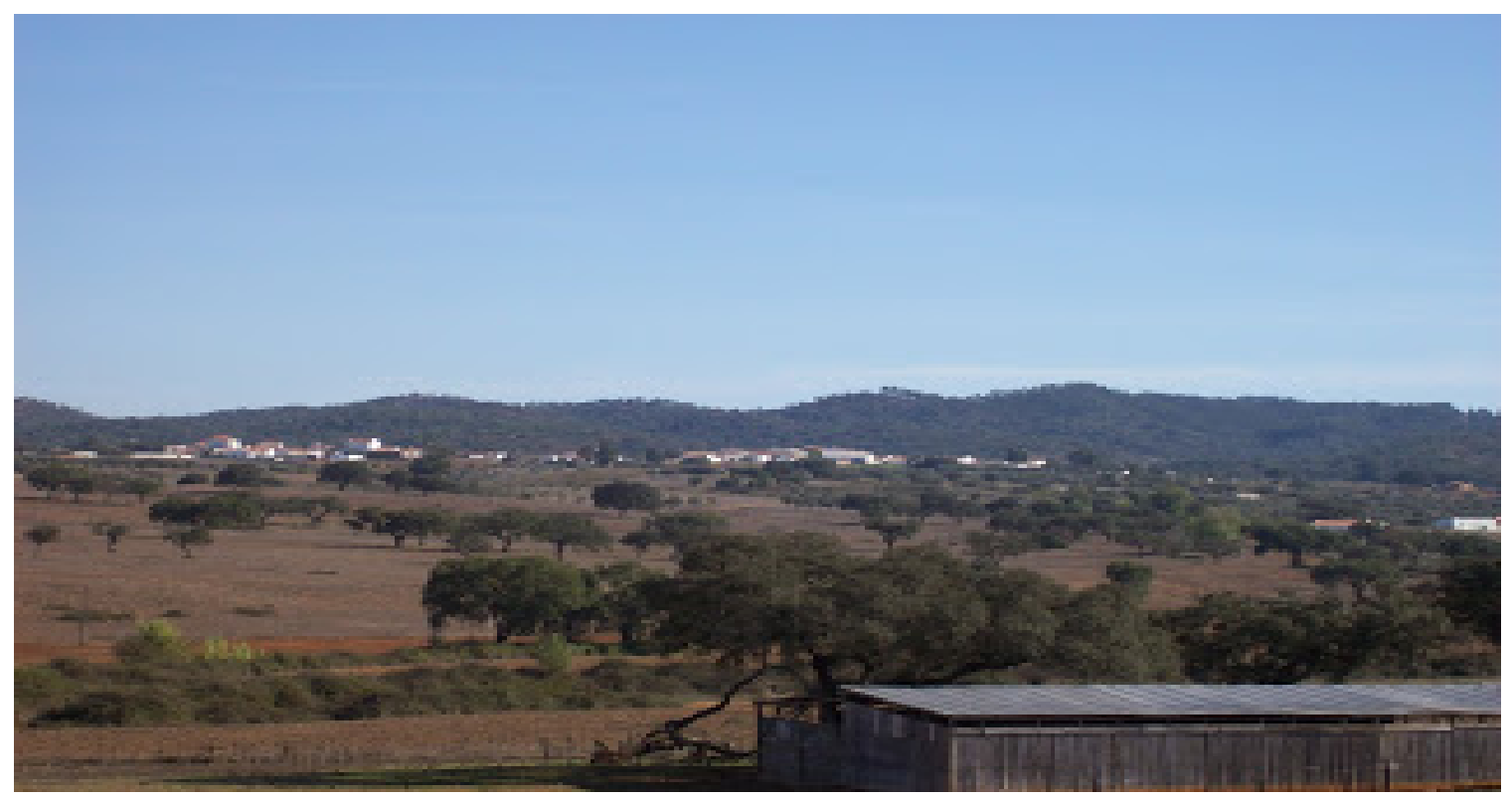

Figure 2: View of Colos from nearby Monte das Ferrarias. Source: aldeiadereliquias.blogspot.pt

\section{The inhabitants, and Tamera training programs}

In 2015 Tamera's 154 hectares were inhabited by 170 permanent community members, a cohort which grew out of the the initial settlement in the mid-1990s (Figure 3). In 2015, nearly two thirds of the inhabitants were German-speaking, originating from Germany, Switzerland and Austria. The remainder came from a variety of countries and regions, including Spain, Israel-Palestine, Italy, Great Britain, France, the USA, Chile and Greece. Only seven were Portuguese, none born or raised in the region. The average age of community members was 35 and there were more women (60\%) than men. Almost thirty inhabitants were under 18 years old. During the early years of Tamera, German was the language mostly used in daily interactions. English was used more from the mid-2000s onwards, due to the entrance of new members. Although, during fieldwork, English was the language most used in gatherings and public events, German was often spoken in public, supported by English translation. Non-native speakers often reported feeling a sense of cultural marginalization and exclusion. A Portuguese member reported to me that such dynamics gave the impression of a "German bubble that is hard to burst." 


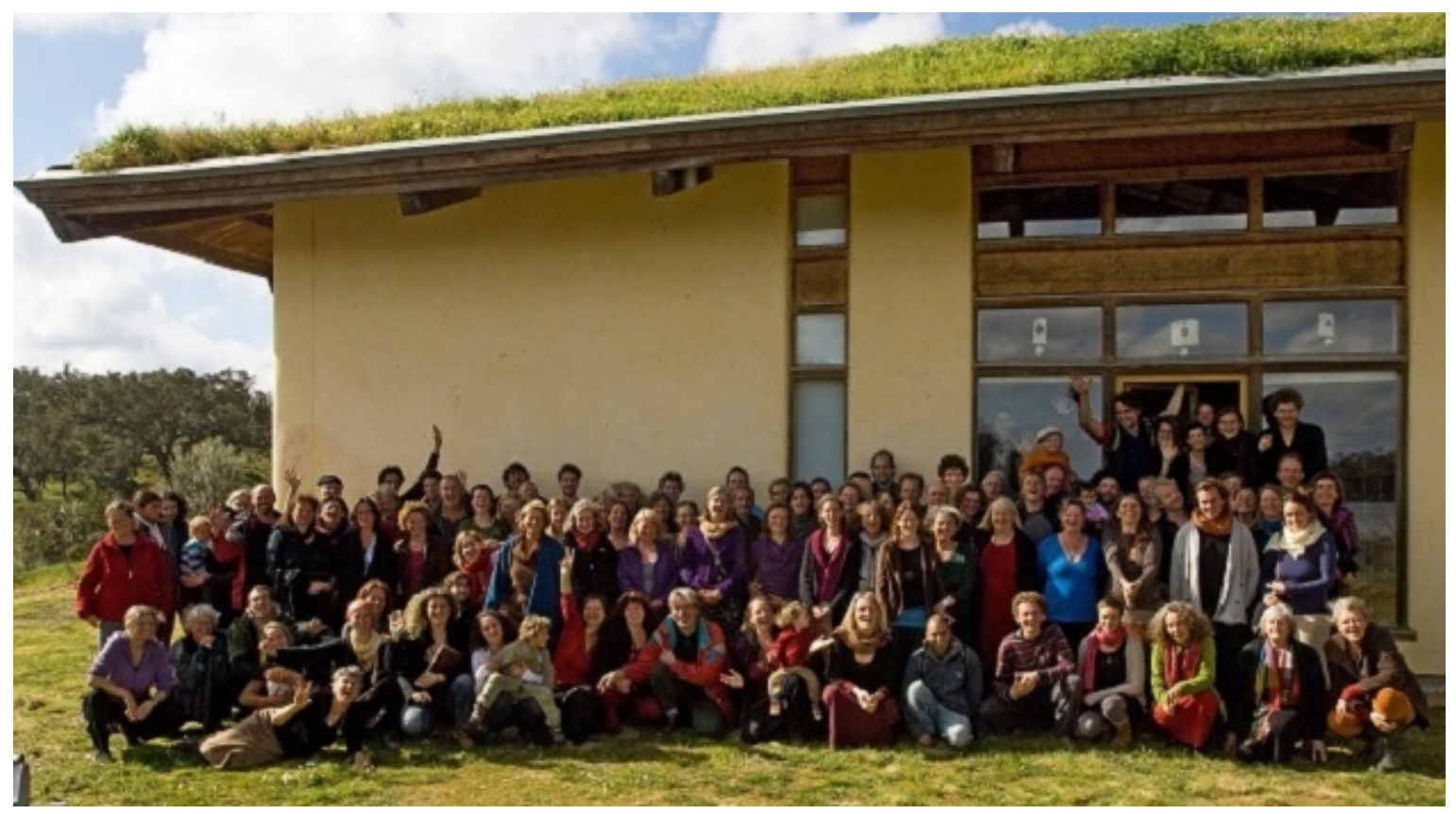

Figure 3: Group picture of the Tamera community. Source: www.tamera.org

The socio-economic standing of Tamera community members contrasts with the surrounding villages, but also Portugal as a whole. This is to a large extent a result of the internal economy of the community, and also because of the criteria for accessing membership, which creates selective pressures that favor people with the following characteristics:

a) those whose middle to upper-class origin gives them a level of autonomy from the labor market and disposable income that grants them time and money to dedicate to the process of entering into the community;

b) those whose fluency in German facilitates access to better paid temporary jobs in Central Europe, where they can raise the funds necessary to cover their expenses while living in Tamera.

Aspiring community members are required to sojourn in Tamera for an extended period as participants in educational initiatives, as well taking the month-long Community Course. ${ }^{20}$ In this program, all the social, ecological and technological aspects of the Healing Biotope model are studied theoretically and experientially in an in-depth, integrated manner. The Community Course has a fee of $€ 750$ (US\$887), as well as a daily rate of $€ 30$ (US\$35) for food and board. For Portuguese participants, the fee was reduced to $€ 500$ (US\$591) and the daily rate to $€ 20$ (US\$24). After the course, new community "joiners" go through a trial period, lasting an average of three years, in which they are "in education." During this period, "joiners" are integrated in one or more of the project teams in Tamera, participate in several internal education initiatives and pay $€ 18$ (US\$21) a day for food and board, regardless of nationality. After being collectively assessed as fit to become community members, the "joiners" are promoted to the first step of becoming a full member of Tamera's communitarian economy, which is that of "co-workers in training." They offer their labor to ensure the overall functioning and development of the project, in exchange for free housing, food, water, energy and use of the infrastructure. After a variable trial period, which in one case took 10 years, "co-workers in

\footnotetext{
${ }^{20}$ https://www.tamera.org/what-is-tamera/visitors3/events/community-course-2015/ (Last retrieved on March 9, 2016.)
} 
training" are promoted to the rank of "co-workers." The difference between the two categories of community members is that "co-workers" receive $€ 200$ (US\$240) of pocket money every month for personal expenses, plus have the duty of helping, when necessary, to cover deficits in the community budget by holding temporary paid jobs outside its premises or contributing their own money. "Co-workers" and "co-workers in training" are covered by a collective health insurance policy that allows them to access health treatments in Portugal or in other EU countries. They also benefit from access to the Posto de Saúde, an internal clinic staffed by doctors and nurses that are either co-workers or members of the network of supporters of the project. The clinic offers its services to community members, as well as to visitors in exchange for donations. In order to be able to live and work in Tamera, "joiners", "co-workers in training" and "co-workers" used external sources of income for personal expenses. These included family allowances, trust funds or retirement pensions, rental income, managing online businesses or working as self-employed service providers in or beyond Portugal. Individuals who didn't benefit from such safety nets worked for an average of one to three months a year in agriculture or service industries in Central Europe, in order to raise money to cover their expenses for the rest of the year in Tamera.

Every year, Tamera receives thousands of visitors during its Guest Season (April-November). During the summer months, its estate hosts up to 500 people at a time. Sources at Tamera's Guest Office indicated that the project was visited by around 3,500 people in 2015, with more than two-thirds being participants in educational and training programs. ${ }^{21}$ Although it was not possible to obtain quantitative data on the nationality of visitors, I noticed during my daily interactions with other guests that the vast majority of participants in Tamera's educational and training initiatives came from Germany, Austria and Switzerland, followed by North America and Israel. The Guest Office confirmed this has been constant for more than a decade. Most of these visitors were people whose financial standing, stage in life or professional status provided them with the money and time to reside for extended periods. The few Portuguese visitors were either higher education students or middle-class professionals and came mostly from the metropolitan areas of Lisbon, Oporto or Coimbra.

The visitor profile is explained by the prices of Tamera education and training programs. The major program is the Ecology Practice or Practical Work in Ecology ${ }^{22}$, through which the participants engage in at least one month of experiential learning, under the supervision of community members, in the food and seed gardens or in a reforestation project. Another key one is the 10 day-long seminar Love, Sexuality, Partnership. $^{23}$ In 2015, participants in Practical Work in Ecology paid €20 (US\$24) per day to participate in the program ( $€ 15$ or US $\$ 18$ for Portuguese). Love, Sexuality and Partnership had a seminar fee of $€ 600$ (US\$709), as well as a daily rate of $€ 30$ (US\$35) for food and accommodation. For Portuguese people, the fee was reduced to $€ 400$ (US\$473) with the same daily rate reduction. Despite the national discount, the programs remained unaffordable for most of the population. According to data published by Instituto Nacional de Estatística (National Institute of Statistics), in 2013 about 20\% of the Portuguese population lived with less than $€ 411$ (US\$486) a month. Only 4\% of people aged 35 or lower earned more than $€ 900$ (US\$1,064) a month.

\section{Ecologies and landscape}

During high summer, an aerial view of Tamera shows its artificial lakes, swales and lush vegetation. It looks like a green, densely populated oasis in the middle of a yellowish, semi-deserted landscape, dotted with cork and oak trees (Figure 4). The regional ecosystem of Alentejo is generally characterized by a high risk of desertification, due to the current quality of soils and land use patterns, and there are predicted increases in

\footnotetext{
${ }^{21}$ At the time of fieldwork, Tamera didn't have publicly available quantitative data that could discriminate visitors taking part in the Open Day Program or who came to Tamera for private visits to community members, from participants in educational and training programs. It was not possible to indicate the total numbers in each program, either in 2015 or for the previous years.

22 https://www.tamera.org/what-is-tamera/visitors3/events/practical-work-ecology-2015/ (Last retrieved on March 7, 2016.)

${ }^{23}$ https://www.tamera.org/what-is-tamera/visitors3/events/love-school-september-2015/ (Last retrieved on March 7, 2016.)
} 
the frequency of droughts, reduced precipitation and increased temperatures (Op. cit.). According to Bernd Walter Müller, the director of Tamera's Global Ecology Institute (GEI), Alentejo has a yearly average amount of rainfall similar to that of Berlin, and one of the highest exposures to sunlight in Europe. However, the extensive agriculture that has been practiced in the region since the mid-20th century impoverished the soil and depleted its capacity to absorb rainwater, contributing to its ecological, economic and demographic decline. The promotion of intensive cereal, quercus (for cork production) and olive tree cultures during the mid- $20^{\text {th }}$ century were part of import substitution policies and support to the war efforts in the former African colonies. The authoritarian governments of Salazar and Marcelo Caetano contributed to a level of soil erosion that affected agricultural productivity in the region well into the $21^{\text {st }}$ century (ENAAC 2010). These factors, together with increased mechanization, as well as market liberalization after accession to the European Communities in 1986 and measures from the European Union's Common Agricultural Policy that restricted cereal, cork and olive oil production in Portugal, led to a drastic reduction in employment in agriculture in Alentejo and a massive migration from rural to urban areas (ENAAC 2010). According to internal sources, the purchase of Monte Cerro by the founders of Tamera was a consequence of this process, as the former owner sold the estate to pay for debts resulting from decreased soil productivity and difficulties in maintaining sales.
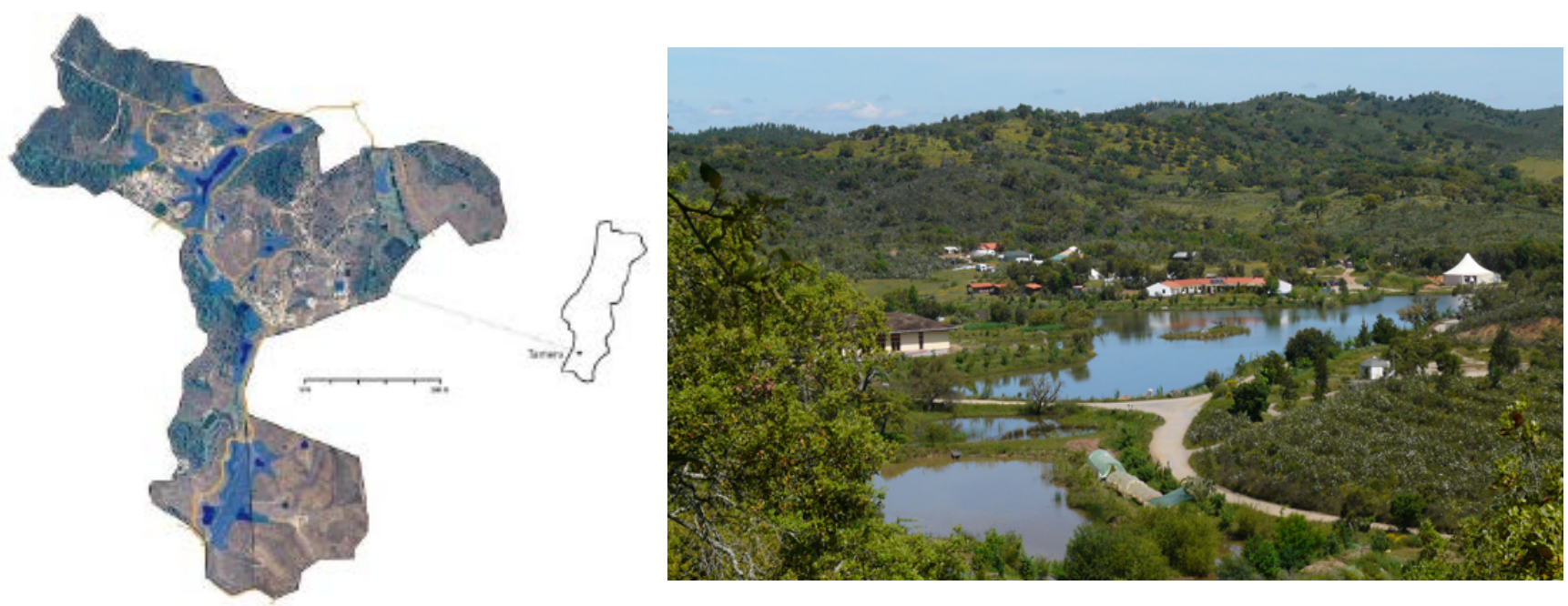

Figure 4: Views of Tamera's water retention landscape (WRL) showing lakes. Sources: Vizinho et.al. 2015: 40, and www.tamera.org.

Tamera took advantage of the abundance of sunshine and rain in the region to begin the development of a commons-based economy, based on a strategy of ecosystem regeneration aimed at promoting autonomy in water, energy and food production. This strategy aims to be recognized as a replicable model for subsistence in autonomous communities, and for climate change mitigation. According to sources from Tamera's Ecology Team, the ecovillage was already producing 54\% of all the electricity consumed within its premises in late 2015. This is thanks to experimental research on renewable energy-based technology that is being developed at Tamera's Test Field 1, including a Solar Village for pumping water, powering greenhouses and food processing and storage. This was envisioned by German physicist Jürgen Kleinwächter, CEO of Sunvention International GmbH. ${ }^{24}$ The system is complemented by Scheffler mirrors,

${ }^{24}$ http://www.bsrsolar.com (last retrieved on January 17, 2017). 
as well as biogas digesters, developed by engineer Thomas H. Culhane ${ }^{25}$, which turn food waste into a source of fuel for food processing, as well as into soil fertilizer. Thanks to a Permaculture system known as the Water Retention Landscape (WRL, Figure 5), which combines rainwater conservation, reforestation and soil regeneration, Tamera became fully autonomous in terms of water usage in 2011. The purpose of the WRL is not to promote complete autonomy in food production, but again to demonstrate how to regenerate ecosystems and sustain life in degraded areas. The soil regeneration promoted by the WRL led to a significant increase in the quantity and diversity of plant species, which, besides serving as an edible "food forest", created a diverse habitat that attracted native wildlife species that have previously disappeared from the area. The increased biodiversity supported the resilience of crops by controlling pests and enhancing pollination. According to Tamera's Ecology Team, thanks to the WRL, in 2015 the community was producing about $14 \%$ of the food consumed within its premises. About $65 \%$ was bought from organic farmers in the region, while the remnant was imported.

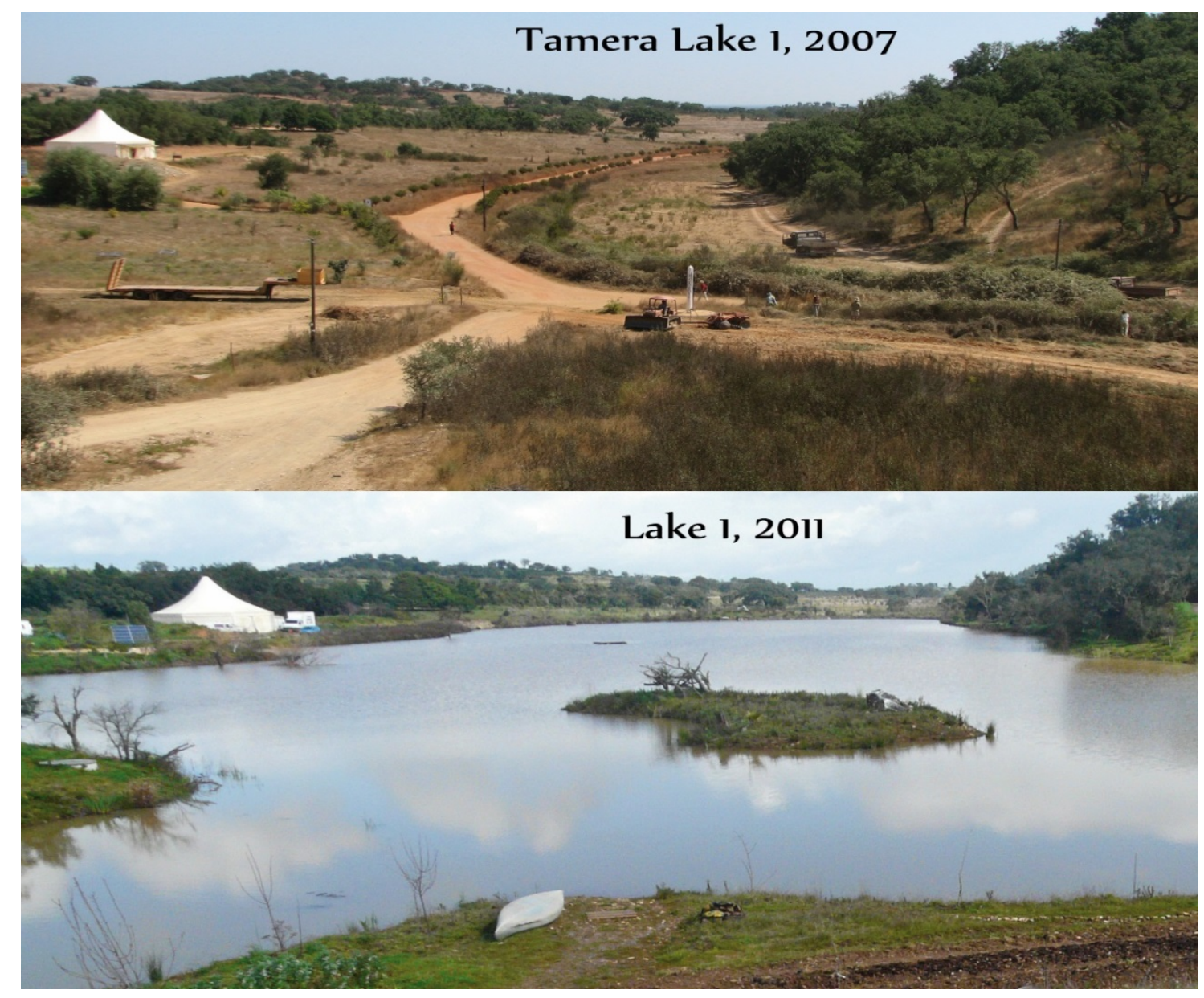

Figure 5: Before and after the construction of Lake 1. Source: Tamera's Ecology Team.

\footnotetext{
${ }^{25}$ Thomas H. Culhane is the founder of Solar CITIES, a non-profit organization that works on capacity building in developing countries through the development of low-cost, high-efficiency biogas systems and system integration training for "food-waste-to-fuel-and-fertilizer" biodigesters at the household and community level: http://solarcities.blogspot.pt/p/what-is- solar-cities-and-how-can-you.html (last retrieved on January 17, 2017).
} 
During a casual conversation, a Tamera community member claimed that:

[t]here are people who argue that this vision of a 'healed' landscape as one that has a lot of water and a lot of green vegetation denotes a Central European bias of what a balanced ecosystem should look like. It's as if a desert, or a semi-arid region, weren't equipped with what's necessary to carry life. They are, in the measure of the latitude where they are located, in the measure of the kind of climate they are exposed to. It's only that the way life manifests in such biomes is much different from the way it manifests in the Alpine region or the great forests of Central Europe. [Fieldwork notes, July 2015]

The European research project Bottom-up climate adaptation strategies towards a sustainable Europe (BASE) indicate that Sepp Holzer's authority and prestige as a Permaculture consultant was a key factor in the introduction of the WRL in Tamera:

Regarding the knowledge and information about climate adaptation, this factor is considered critical since it was, together with the other factor of the consultant's opinion and knowledge, the main two factors that enabled the adoption of the Water Retention Landscapes. The reason is that the knowledge of the consultant about creating landscapes adapted to the climate (inspired also by Permaculture Design) and its capacity to convince and mobilize the ecovillage of Tamera to take on this multifunctional investment were determinant for the adoption of the adaptation action. (Vizinho et al. 2015: 59)

But has it worked? The evidence seems mixed. A retrospective analysis of Tamera's WRL as an adaptation measure for droughts and water scarcity for the Alentejo region, carried out by BASE indicate that, from the perspective of the biophysical conditions of Alentejo at the time of fieldwork, the WRL doesn't seem to bring significant advantages when compared with other possible approaches. The construction of artificial lakes led to an overall increase of carbon sequestration, of 9.4\% per year between 2006 and 2014. However, this was mainly due to the replacement of grasslands by lakes (Vizinho et al. 2015: 59-60). Where land use change from broad-leaf forest to water occurred, the difference in carbon storage was actually negative. Increases in nitrogen, resulting from the development of vegetable gardens around the artificial lakes, did not exceed the critical loads of broadleaved deciduous and Mediterranean evergreen Quercus woodlands: 10-20 kg yr ${ }^{-1}$. This indicates that, looking at carbon storage alone, reforestation by Mediterranean evergreen broad-leaf forest (Montado) might be a more effective strategy for climate change mitigation in this biome than the WRL (Op. cit. p.53). However, when making a prospective analysis that takes into account possible future scenarios of increased drought frequency and intensity and reduced annual precipitation from climate change, the WRL appears to be more efficient in terms of water storage and provision for crops and livestock, reducing losses from long droughts (Op. cit.).

The data collected by the BASE team indicate that the benefits of the WRL extend beyond Tamera. In the surrounding area, transitional woodlands increased from 9.34 ha to 19.50 ha mainly in areas previously occupied by natural grasslands. This led to the increase in carbon storage reported above. Besides, soon after "Lake 1" was created, a new spring appeared, feeding a small stream which flows from Tamera to the neighboring land all year round. Thus, the lakes also support neighbors and firefighters in times of drought or fire, therefore increasing security and ecosystemic resilience. The value of resilient ecosystems will rise if water insecurity worsens in the region, but projections are too uncertain to be quantified. ${ }^{26}$

The team calculated economic benefits resulting from the WRL through proxy measures and value estimates. The major benefit for Tamera is an estimated added net income for 2014-2050 of €810,000 (US\$

26 http://climate-adapt.eea.europa.eu/metadata/case-studies/tamera-water-retention-landscape-to-restore-the-water-cycleand-reduce-vulnerability-to-droughts/\#cost_benefit_anchor (last retrieved on January 17, 2017). 
957,500), resulting from visitor fees and educational events such as a Water Symposium and Permaculture seminars. But the lakes were expensive to construct, leading to estimated net losses of -€261,551 (US\$309,000) over this time. Of course the community considered aesthetics, beauty, leisure and recreation to be worth the financial expenditure. And the better water storage, availability and water quality would probably increase land values between $€ 150,000$ to $€ 400,000$ (US\$177,300-US\$472,800). ${ }^{27}$

Despite the WRL's multiple benefits, it would be hard to replicate across the region, which is poor, and now subject to stricter land use regulations (much of the WRL was built un-permited). In the words of a Tamera neighbor:

[t]he Water Retention landscape is a project of huge dimensions, which implies a lot of costs. Even if the local population has any interest in this system, how can it actually be reproduced? The people of the region are, in their vast majority, very poor. They do not have the necessary financial means. The rural properties are also not big enough for it. Besides, there is the RAN, the 'Reserva Agrícola Nacional', which sets limits for construction. [Fieldwork notes, October 2015]

There is also concern that rising land values begun by Tamera could provoke further rural gentrification, which is already underway. Kunze and Avelino's study on social innovation in the Global Ecovillage Network (2015) includes Tamera as one of its case studies .They argue is has "(...) a double-sided impact (...) on the surrounding rural region" which has much in common with "(...) the typical gentrification impacts of alternative sustainability initiatives in urban areas." (p. 5). Tamera community members and visitors have a positive impact on the regional economy, namely by supporting the production and commercialization of regional ecological and organic products. Vegetarian restaurants have opened in nearby villages, and local bakers sell German-style wholemeal organic bread. Many producers, organic farmers and shops in the regions believe that they would "not survive without Tamera" (p. 5). This may be the development of regional sustainability that the project has sought. But Kunze and Avelino show property prices in the vicinity have risen, pushing out local residents. This is to a large extent the result of the growing number of Central and Northern European expatriates moving to the area, many of whom attracted by Tamera and its activities. They have bought properties to develop homesteads or intentional communities while still being able to participate in Tamera.

\section{Bridging the "borderland": cultural rapprochement and institutional dialogue}

Some of the founding community members said the project had two distinctive periods. The first decade was spent relatively isolated from their regional neighbors, as the Healing Biotope model evolved. The mid-2000s marked the development of more regional relationships. There was cultural rapprochement with the population and culture of southwestern Alentejo, and institutional dialogue with the municipality of Odemira to develop a regulatory framework for regional sustainable development in which Tamera could operate.

In 2006, Tamera started the three-year "Monte Cerro experiment", an international residential peace education program that was publicized internationally, especially through the online channels of the Global Ecovillage Network. The program attracted a cohort of participants that originated predominantly from German-speaking countries (including two Greek citizens who resided in Germany). However, it also included Jewish and Arab- Israeli citizens, who learned about Tamera during Sabine Lichtenfels' visit to Israel-Palestine the previous year, and three Portuguese who later became residents. One of them was a "neorural" settler who had recently moved to the region after quitting a career in Lisbon as a geologist. The rationale revealed to me was a revolt against environmentally unethical practices in the profession, as well as a desire to follow a lifestyle that was coherent with principles of social and environmental sustainability. The two others got to know about the project through online channels while studying in the United Kingdom. One

\footnotetext{
${ }^{27}$ Idem
} 
of them quit the program after one year, claiming an incompatibility of values and lifestyle. The other lived in Tamera until 2012 and soon after became a staff member at GEN headquarters. ${ }^{28}$

These Portuguese newcomers were instrumental in the development of cultural rapprochement with the population in the region, as well as the Portuguese public in general. It included translating Tamera's webpage into Portuguese, and establishing linkages with journalists, documentary filmmakers, academic researchers and political activists. It meant establishing closer relations with the authorities and the inhabitants of the region, with the support of neighbouring villagers who, having lived and worked for many years in Central or Northern Europe, became cultural mediators. The multilingual family that owns the Café Marco in Reliquias, returned to Portugal after living in Germany and France for nearly two decades. Their business became the main dining and snacking spot for Tamera community members, facilitating dialogue and exchange with the locals. A patron of Café Marco who was also the elected president of the Junta de Freguesia (village-level municipal administration) in 2015, explained the role of former emigrants:

(...) there were always conversations over beer or coffee, and people find they have interests in common. (...) We have Portuguese people, natives of this village, who lived in Germany or France. They invited them to their houses for tea. They have another understanding of their reality. (...) They and their guests also have a big impact in the local economy. They bring a lot of money to businesses in the area, cafés, restaurants, shops, the cooperative. They also order a lot of products from local farmers. (...) Thanks to these exchanges, people started opening up more. (...) A lady from Tamera now gives classes on medicinal herbs at the Cooperative. The local ladies come and also share their knowledge on medicinal teas and cooking herbs.

The same informant, who was an urban migrant for a long time before returning to his home village, also explained the role that public authorities have been playing in this process of cultural mediation:

Then I started taking groups of people there. It was my own initiative. Nowadays the Junta de Freguesia organizes regular walks to Tamera. Thanks to these walks, the older folks started to realize that what they do in the Water Retention Landscape is not new for us. That's what we used to do here in the older times, the retention of rainwater in man-made puddles in the back yards. The older folks look at that and say "That's what we used to do, that's what our parents did." Like with composting. (...)

A core aspect of this mediation is the integration of Tamera community members in sports and cultural events organized by the villagers:

The biggest opening was about five years ago, thanks to the football matches we organize with the support of Junta de Freguesia. People invited them to take part in local amateur teams, and things developed from there.(...) We also have a yearly Tamera/Reliquias football match. (...) Now we have "mixed" village parties, with folk music. The Tamera choir is invited to perform at those parties. The choir sings in the Church at Christmas. They carry the statues of the saints during the processions. Every Easter, we invite them to take part in the procession and they carry palm and olive branches. They always send people to take part in the organizing team of our regular village markets. They sell medicinal herbs, teas, tree buds. The revenue contributes to the construction of the senior citizen's home here in the village. [Interview 14, October 2015]

\footnotetext{
${ }^{28}$ The other Portuguese community members joined Tamera in the late 2000s and early 2010s as "joiners", after attending the Community Course.
} 
Eventually a partnership formed between Tamera and the local public authorities, facilitated by the mediation and representative role assumed by Portuguese community members with inside knowledge of the organizational culture of municipal-level public administration. They are now in the Juntas de Freguesia in Odemira, and deliberations have been held over laws, policies and regulations, as well as state/civil society joint initiatives to fight poverty and promote social cohesion in the region. Tamera also organizes regular open days with guided tours in exchange for a small donation, and there are talks and workshops in Portuguese on the social, technological and ecological research that takes place at the project.

In March 2015 the municipal authorities of Odemira approved the terms of reference for PIER Plano de intervenção em espaço rural, which will result in regulations for the Tamera site and beyond. The ToR indicate that the PIER will change some of the construction limits set up in the Plano de desenvolvimento municipal ${ }^{29}$ (PDM) of August 2000, in exchange for the preservation of ecosystems of high ecological value for the region. The purpose is to integrate the land use and sustainable construction techniques developed in Tamera into the political landscape and regulatory framework of the region. The terms of reference also awarded Tamera a permanent public certification as a research and development centre authorized to use its premises for tourism and hosting events by other organizations for a fee, as well as to commercialize agricultural products and renewable energy technology. By 2015, the dialogue between Tamera and the public authorities was still ongoing.

\section{Conclusions}

Tamera's trajectory illustrates the exclusionary dynamics that may emerge when the envisioning of a commons-based alternative political ecology is not accompanied by an alternative political economy. The essential feature is that Tamera transplanted and developed an 'ideal type' Healing Biotope model, as well as a prefigurative process of "commoning" to rural southwestern Alentejo. This created a borderland (Anzaldúa 1987) which spatially segregates, and at the same time creates a point of contact between two contrasting cultural, ecological and socio-economic realities. The most visible aspect of the borderland is the Water Retention Landscape (WRL). With origins in the alpine region of Central Europe, it was used restore a degraded Iberian semi-arid ecosystem suffering from import-substitution agricultural policies. The EU Common Agricultural Policy further contributed to the natural and human desertification of the region. The borderland created by Tamera also has a cultural and socio-economic dimension: estrangement between the post-materialist values of the middle and upper classes of Central Europe and other parts of the industrial world, and the predominantly heteropatriarchal, socially conservative culture of the impoverished villages of the region.

The fact that the large majority of the visitors to Tamera came from the same part of the world and had a similar socio-economic profile as its founding members illustrates the tendency for social homogeneity within ecovillages. This did grant Tamera access to financial resources to guarantee its economic sustainability, as well as the development of the WRL. It also promoted a prefigurative dynamic that granted Tamera enough political power to counter existing regional, national and supranational-level regulations, as well as (eventually) working with the municipal-level administration to develop a new regulatory framework, PIER. The fact that Tamera and its visitors have a positive effect on the economy of the region contributed to this outcome. The efforts of cultural mediation that Tamera has been promoting with the support of Junta de Freguesia, as well as returnees to the region, helps cross the social borderlands to the local population, and increases the project's political capital.

Regional political ecology, in this unusual case, sheds light on how a synergy between the ecological and social dimensions of "commoning" contributed to the reimagination of politics over time, leading to the creation of the building blocks needed for a bottom-up system of counter-power. But also, counter-power led to exclusionary socio-economic and territorial practices of "communing" in the first place. This poses a real challenge to law-makers and activists - how to integrate ecovillages into place-based processes of regional development? It also raises the question of how to develop regulatory and financial instruments that support ecovillages while still being socio-economically inclusive, as they continue to experiment. Beyond counter-

\footnotetext{
${ }^{29}$ Municipal Development Plan.
} 
cultural niches, ecovillages need to adopt strategies of communication in the public sphere that reach and effectively engage the wider public.

\section{References}

Altvater, E. 2005. Global order and nature. In R. Keil, D.V.J. Bell, P. Penz and L. Fawcett (eds.). Political ecology: global and local. London: Routledge. Pp. 19-44. Researchgate

Alves, F.M., G. Penha-Lopes, A. Vizinho, I. Campos, C. Ulbig, C. Branquinho, D.P. Godinho and A. Santos. 2015. An economic analysis of rural climate change adaptation to droughts: the case of the Tamera Water Retention Landscape, Portugal. BASE - Bottom-Up Climate Adaptation Strategies for Europe, Grant Agreement No. 308337, Internal draft report, July 30, 2015. Researchgate

Anzaldúa, G. 1987. Borderlands/la frontera: the new mestiza. San Francisco: Aunt Lute Books.

Barker, E. 2014. The not-so-new religious movements: changes in 'the cult scene' over the past forty years. Temenos. 50(2): 235-256.

Berman, M. 1988. All that is solid melts into air: the experience of modernity. New York: Penguin Books.

Blaikie, P.M. 1985. The political economy of soil erosion in developing countries. London:

Bollier, D. and S. Helfrich (ed.). 2012. The wealth of the commons: a world beyond market and state. Amherst, MA: Levellers Press.

Bollier, D. and S. Helfrich. 2015. Patterns of commoning. Amherst, MA: Levellers Press.

Buell L. 2001. Writing for an endangered world: literature, culture, and environment in the U. S. and beyond. Cambridge: Harvard University Press.

Burke, B.J. and B. Arjona. 2013. Creating alternative political ecologies through the construction of ecovillages and ecovillagers in Colombia. In Lockyer, J. and J.R. Veteto (eds.). 2013. Environmental anthropology engaging ecotopia. bioregionalism, permaculture, and ecovillages. New York: Berghahn Books. Pp. 235-250.

Carfagna L.B., E.A. Dubois, C. Fitzmaurice, M.Y. Ouimette, J.B. Schor and M. Willis. 2014. An emerging eco-habitus: the reconfiguration of high cultural capital practices among ethical consumers. Journal of Consumer Culture 14(2): 158-178. draft

Dawson, J. 2012. From islands to networks: an exploration of the history - and a glimpse into the future - of the ecovillage movement. In Lockyer, J. and J.R. Veteto (eds.). 2013. Environmental anthropology engaging ecotopia. bioregionalism, permaculture, and ecovillages. New York: Berghahn Books.

Duhm, D. 2015. Terra nova: global revolution and the healing of love. Bad Belzig, DE: Verlag Meiga.

Duhm, D. 2016. Der immanente Gott: fundamente der befreiung. Bad Belzig: Verlag Meiga.

De Angelis, M. 2014. Social revolution and the commons. South Atlantic Quarterly 113(2): $299-311$.

ENAAC. 2010. Resolução do Conselho de Ministros n.o 24/2010. Diário da República, 1.a série - N.o64. Lisboa: Presidência do Conselho de Ministros, Estratégia Nacional de Adaptação às Alterações Climáticas.

Escobar, A. and S.E. Alvarez (eds.). 1992. The making of social movements in Latin America: identity, strategy and democracy. Boulder, CO: Westview Press.

Federici, S. 2012. Feminism and the politics of the commons. In Bollier, D. and S. Helfrich (ed.). 2012. The wealth of the commons: a world beyond market and state. Amherst, MA: Levellers Press. Pp. 45-5.

Gilbert, K. 2014. Communes still thrive decades after the 60s, but the economy is a bummer, man. Al Jazeera America, December 5. http://america.aljazeera.com/multimedia/2014/12/communes-stillthrivedecadesafterthe60sbuteconomyisabummerman.html [last retrieved on January 11, 2017].

Gilman, R. 1991. The eco-village challenge. In Context 29.

Habermann, F. 2012. We are not born as egoists. In Bollier, D. and S. Helfrich (ed.). 2012. The wealth of the commons: a world beyond market and state. Amherst, MA: Levellers Press. Pp. 13-18.

Harribey, J.M. 2011. Le bien commun est une construction sociale. Apports et limites d'Elinor Ostrom. L'Économie politique 49: 98-112.

Harvey, D. 2011. The future of the commons. Radical History Review 109: 101-107. 
Howitt, R. 2006. Scales of coexistence: tackling the tension between legal and cultural landscapes in postMabo Australia. Macquarie Law Journal 6(1): 49-64.

Inglehart R. 1997. Modernization and postmodernization. Princeton: Princeton University Press.

Jackson, R. 2004. The ecovillage movement. Permaculture Magazine (Summer).

Joubert, K. and R. Alfred (ed.). 2014. Beyond you and me: inspirations and wisdom for building community. East Meon, UK: Permanent Publications.

Kunze, I. and F. Avelino. 2015. Social innovation and the global ecovillage network research report. TRANSIT: EU SSH.2013.3.2-1 Grant agreement no: 613169.

Larsen, S.C. 2016. Regions of care: a political ecology of reciprocal materialities. Journal of Political Ecology 23: 159-166

LeVasseur, T. 2013. Globalizing the ecovillage ideal: networks of empowerment, seeds of hope. In Lockyer, J. and J.R. Veteto (eds.). 2013. Environmental anthropology engaging ecotopia. bioregionalism, permaculture, and ecovillages. New York: Berghahn Books. Pp. 251-286.

Litfin, K. 2013. Ecovillages: lessons for sustainable community. Cambridge: Polity Press.

Lockyer, J. and J.R. Veteto. 2013. Environmental anthropology engaging ecotopia: an introduction. In Lockyer, J. and J.R. Veteto (eds.). 2013. Environmental anthropology engaging ecotopia. bioregionalism, permaculture, and ecovillages. New York: Berghahn Books. Pp. 1-31.

Meretz, S. 2012. The structural communality of the commons. In Bollier, D. and S. Helfrich (ed.). The wealth of the commons: a world beyond market and state. Amherst, MA: Levellers Press. Pp. 28-34.

Nabhan, G.P. 1997. Cultures of habitat: on nature, culture, and story. Washington DC: Counterpoint.

Ostrom, E. 1990. Governing the commons: the evolution of institutions for collective action. Cambridge: Cambridge University Press.

Ray, P.H. and S.R. Anderson. 2000. The cultural creatives: how 50 million people are changing the world. New York: Harmony Books.

Rocheleau, D. 2011. Rooted networks, webs of relation, and the power of situated science: bringing the models back down to Earth in Zambrana. In M. Goldman, P. Nadasdy and M. Turner (eds.) Knowing nature, transforming ecologies: a conversation between science and technology studies and political ecology. Chicago: University of Chicago Press. Pp. 209-226.

Schor, J.B., C. Fitzmaurice, L.B. Carfagna, W. Atwood-Charles and E.D. Poteat. 2016. Paradoxes of openness and distinction in the sharing economy. Poetics 54: 66-81

Snyder, G. 1995. A place in space: ethics, aesthetics, and watersheds. Washington DC: Counterpoint.

Tibbs, H. 2011. Changing cultural values and the transition to sustainability. Journal of Futures Studies 15(3): 13-32.

Veltmeyer, H. and J. Petras. 2000. The dynamics of social change in Latin America. London: Macmillan.

Vizinho, A., I. Campos, F.M. Alves, A.L. Fonseca and G. Penha- Lopes. 2015. Adaptation to drought in Alentejo, Portugal. BASE - Bottom-Up Climate Adaptation Strategies for Europe. FP7/ Project BASE [2012-2016], Grant Agreement No. 308337. 